\title{
PENINGKATAN KINERJA MENGAJAR GURU MELALUI PENERAPAN MANAJEMEN PENGETAHUAN DAN PENGEMBANGAN KAPASITAS GURU MADRASAH ALIYAH DI KOTA BANDUNG
}

\author{
Suryadi, Johar Permana \\ Universitas Pendidikan Indonesia \\ suryadi@upi.edu, joharpermana@upi.edu
}

\begin{abstract}
This study aimed to describe and analyze the knowledge management and capacity development of teachers Madrasah Aliyah in Bandung. Analytic descriptive method with quantitative approach used in this study on 225 respondents. The result: There is a significant effect simultaneously knowledge management, capacity building of teachers to the teacher's teaching performance MA in Bandung, knowledge management and capacity development of teachers are in the category enough. Personal dimension, procedures and technologies with category enough. Dimension policy, management, quality assurance, impact category enough.
\end{abstract}

Keywords: Knowledge Management, Capacity Building, Teaching Performance

\section{A. PENDAhuluan}

Sumber daya manusia merupakan aset yang paling penting dalam suatu organisasi karena sumber daya manusia memiliki peranan sebagai subyek pelaksanaan kebijakan dan kegiatan operasional organisasi tersebut. Keberadaan sumber daya manusia sangat erat kaitannya dengan kinerja organisasi, yaitu kemampuan melaksanakan tugas-tugas yang dibebankan kepada organisasi dengan sebaik-baiknya guna mencapai sasaran yang telah disepakati.

Pengembangan kapasitas sumber daya manusia terus diupayakan oleh pemerintah melalui berbagai kebijakan salah satunya dengan terbitnya Undang-undang Nomor 20 tahun 2003 tentang Sistem Pendidikan Nasional. Dalam pasal 3 UUSPN No. 20 tahun 2003 dijelaskan bahwa Pendidikan Nasional berfungsi mengembangkan kemampuan dan membentuk watak serta peradaban bangsa yang bermartabat dalam rangka mencerdaskan kehidupan bangasa, bertujuan untuk mengembangkan potensi siswa agar menjadi manusia yang beriman dan bertakwa kepada Tuhan Yang Maha Esa, berakhlak mulia, sehat, berilmu, cakap, kreatif,mandiri dan menjadi warga negara yang demokratis serta bertanggungjawab. Peningkatan sumber daya manusia dan peningkatan kualitas pendidikan harus dimulai dengan peningkatan kualitas guru menuju guru profesional dan bermutu, yang sampai saat ini masih banyak kendala dan tantangan yang dihadapi, terutama pelaksanaan pembelajaran. (Surya, 2007) mengungkapkan berbagai masalah dan kendala yang berkaitan dengan kondisi guru, antara lain berkaitan dengan kualitas, keadilan, kesejahteraan guru dan manajemen sumber daya manusia (guru). Bagaimana mereka dapat menghantarkan siswa untuk mendapatkan nilai ujian nasional minimal 5,5 kalau gurunya saja tidak mampu menembus bahkan di bawah angka standar tersebut. Hal ini diperkuat dengan hasil uji kompetensi guru (UKG) pada bulan November 2015 yang menunjukkan rata-rata hasil UKG Nasional sebesar 53,05, sedangkan pemerintah menargetkan rata-rata nilai di angka 55. Selain itu, rerata nilai profesional 54,77 sedangkan nilai ratarata kompetensi pendagogik 48,94. 
Fenomena tersebut, di perkuat melalui hasil studi pendahuluan (pra survey) yang peneliti lakukan secara acak terhadap 20 orang guru yang ditempatkan di kabupaten Bandung yang menunjukkan bahwa: (1) Variasi pada dimensi kualitas mengajar di lihat dari memahami karakteristik belajar siswa, menguasai teori belajar, melakukan pembelajaran, mengetahui potensi siswa, melakukan penilaian, melakukan pembimbingan, dan waktu mengajar oleh guru madrasah; (2) Variasi Inisiatif guru terkait pengembangan kapasitas dirinya; (3) Variasi pertukaran pengetahuan; (4) Variasi pemanfaatan teknologi informasi komunikasi dalam pembelajaran; (5) Variasi kesesuaian pengembangan kapasitas dengan kinerja mengajar; dan (6) Variasi dampak hasil pengembangan kapasitas guru.

Berdasarkan identifikasi masalah di atas, maka dirumuskan masalah sebagai berikut: (1) Bagaimana gambaran manajemen pengetahuan, pengembangan kapasitas guru, kinerja mengajar guru pada Madrasah Aliyah di Kota Bandung ?; (2) Sejauhmana pengaruh manajemen pengetahuan dan pengembangan kapasitas guru terhadap kinerja mengajar guru pada Madrasah Aliyah di Kota Bandung.

Tujuan penelitian ini adalah untuk mengetahui dan menganalisis : (1) Deskripsi manajemen pengetahuan, pengembangan kapasitas guru, kinerja mengajar guru pada Madrasah Aliyah di Kota Bandung (2) Pengaruh manajemen pengetahuan dan pengembangan kapasitas guru terhadap kinerja mengajar guru pada Madrasah Aliyah di Kota Bandung secara parsial dan simultan. Manfaat bagi penelitian ini adalah bahwa madrasah dapat mengoptimalkan peran manajemen pengetahuan untuk meningkatkan kinerja mengajar guru untuk keberlangsungan dan keberlanjutan pendidikan madrasah, madrasah dapat mengoptimalkan peran pengembangan kapasitas guru untuk meningkatkan kinerja mengajar guru untuk keberlangsungan dan keberlanjutan pendidikan madrasah, pengembangan keilmuan manajemen pengetahuan dan pengembangan kapasitas guru untuk meningkatkan kinerja mengajar guru.

Belajar dalam era pengetahuan seperti sekarang ini sangatlah berbeda dengan belajar di masa lalu. Saat ini kita dituntut untuk belajar baik sendiri maupun bersama dengan cepat, mudah dan gembira, tanpa memandang waktu dan tempat. Hal ini mendorong berkembangnya konsep organisasi belajar (learning organization) yang menyatukan antara proses belajar dan bekerja. Hal ini menyebabkan para pakar manajemen mencari pendekatan untuk mengelola pengetahuan yang sekarang dikenal dengan manajemen pengetahuan atau knowledge management. Menurut Davenport, manajemen pengetahuan adalah proses menterjemahkan pelajaran yang dipelajari, yang ada dalam pikiran seseorang menjadi informasi yang dapat digunakan setiap orang. Pendapat lain menyatakan bahwa, manajemen pengetahuan adalah suatu disiplin yang memperlakukan modal intelektual aset yang dikelola (Jerry Honeycutt, 2000). Sebab menurutnya konsep manajemen pengetahuan (knowledge management) pada dasarnya adalah berkembang dari kenyataan bahwa dimasa sekarang dan dimasa depan, aset utama sebuah organisasi agar mampu berkompetisi adalah aset intelektual atau pengetahuan bukan aset kapital. Banyak fungsi yang dihasilkan dari manajemen pengetahuan. Menurut Frappaolo dan Toms (2000), fungsi aplikasi manajemen pengetahuan dalam suatu organisasi ada lima, yaitu intermediation, externalization; internalization, cognition, dan measurement.

Bernardin dan Russell (1993:379) menyebutkan bahwa: "Performance is defined as the record of outcomes produced on a specified job function or activity during a specified time period". Kesimpulan yang dapat diambil dari beberapa pendapat ahli, yaitu pendapat Gomes (2003:142), Rivai (2005:14), Griffin (1987:67), Casio (1992:137), 
Donnelly, et al. (1994:210), Bernardin dan Russell (1993:379).

\section{B. KAJIAN LITERATUR}

Secara kualitas kondisi guru belum cukup untuk menghadapi lajunya pertambahan peserta didik, serta tuntutan pembangunan dan perkembangan zaman. Hasil penelitian Djoyonegoro (2004/2005), menunjukkan bahwa hanya $43 \%$ guru di Indonesia yang memenuhi syarat profesional. Hasil penelitian Sudjana (2006:42) menunjukkan bahwa 76,6\% hasil belajar peserta didik dipengaruhi oleh kinerja mengajar guru, dengan rincian: kemampuan guru mengajar memberikan sumbangan sebesar $32,43 \%$, penguasaan materi pelajaran memberikan sumbangan sebesar 32,38\% dan sikap guru terhadap mata pelajaran memberikan sumbangan sebesar 8,60\%. Menurut Bhatt (2000) bahwa Manajemen Pengetahuan memiliki elemen yang saling terkait satu sama lain, yaitu: people, process, dan technology. Bahkan dikatakan bahwa manajemen pengetahuan itu sendiri tak lain adalah integrasi dari people dan process, yang kemudian dimungkinkan dengan technology, untuk memfasilitasi pertukaran informasi, pengetahuan, dan keahlian sehingga meningkatkan kinerja organisasi. Simamora (2004:339) adalah bahwa kinerja merupakan tingkat keberhasilan yang diraih oleh pegawai dalam melakukan suatu aktivitas kerja dengan merujuk kepada tugas yang harus dilakukannya.

\section{METODE PENELITIAN}

Berdasarkan variabel yang diteliti maka jenis penelitian ini merupakan penelitian deskriptif dan dengan metode kuantitatif. Metode analisis data yang digunakan dalam penelitian ini adalah analisis jalur () karena peneliti ingin memastikan apakah ada pengaruh antara penerapan manajemen pengetahuan dan pengembangan kapasitas guru terhadap kinerja mengajar guru. Model analisis jalur adalah sebagai berikut:

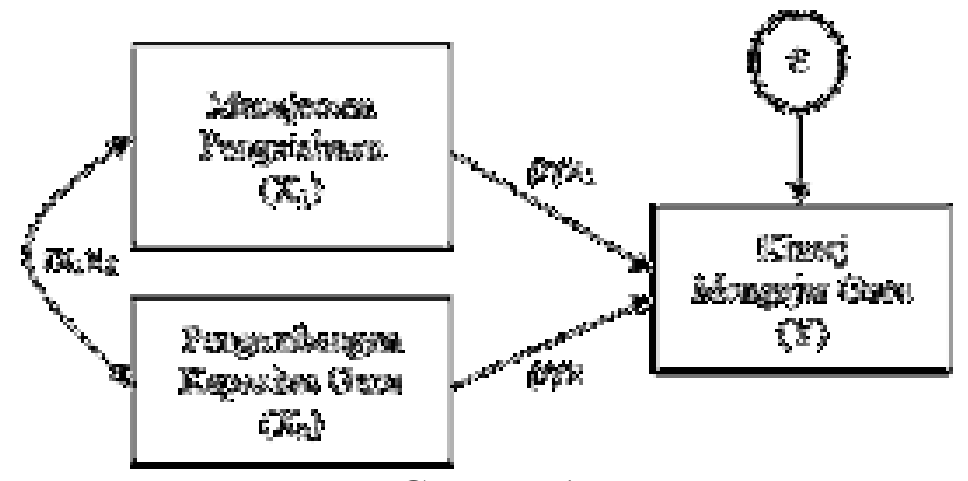

Gambar 1

Analisis Jalur

Gambar ini melukiskan adanya hubungan antara variabel eksogen yaitu X1 dan X2 dengan variabel endogen yaitu Y. Setiap variabel baik eksogen maupun endogen digambarkan dalam bentuk persegi atau kotak sedangkan error $(\varepsilon)$ atau variabel lain diluar $\mathrm{Y}$ digambarkan dalam bentuk lingkaran. Hubungan antara X1 dan X2 menggambarkan hubungan korelasi, sedangkan hubungan antara $\mathrm{X} 1$ dan $\mathrm{X} 2$ terhadap $\mathrm{Y}$ menggambarkan hubungan pengaruh (causal path). Pengaruh dari X1 dan X2 terhadap Y disebut pengaruh langsung (direct effect), sedangkan dari $\mathrm{X} 1$ terhadap $\mathrm{Y}$ melalui $\mathrm{X}$ 2, dari X2 terhadap Y melalui X1 disebut pengaruh tidak langsung (indirect effect).

\section{HASIL DAN PEMBAHASAN}

Berdasarkan hasil penelitian, diperoleh temuan sebagai berikut. Pertama, gambaran penerapan 
manajemen pengetahuan adalah sebagai berikut:

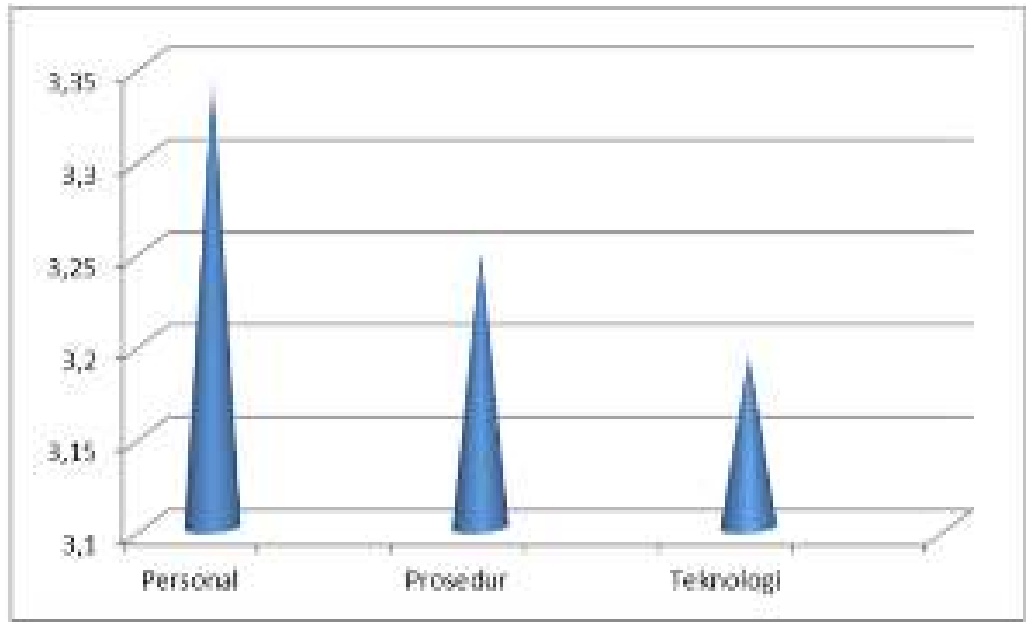

Gambar 2

Deskripsi Dimensi Manajemen Pengetahuan

Diketahui bahwa variabel manajemen pengetahuan memiliki skor rata-rata 3,262 berarti nilai tersebut masuk dalam kategori sedang atau cukup tinggi. Pada variabel manajemen pengetahuan ini nilai tertinggi berada pada dimensi "personal" dengan skor 3,343 dan nilai terendah berada pada dimensi "Teknologi" dengan skor 3,193. Hasil ini menunjukkan bahwa penerapan manajemen pengetahuan pada madrasah aliyah di kota Bandung sudah berjalan dengan cukup baik. Hal ini menggembirakan karena beberapa manfaat dari penerapan manajemen pengetahuan (Skyrme dan Amidon, 1997) adalah sebagai berikut: (1) mengetahui dan menyadari nilai asset yang sulit dinilai (intangible asset); (2) memiliki kesempatan untuk meningkatkan nilai tambah pada proses urusan pokok; dan (3) menyebarluaskan praktik yang benar dengan berbagi pengetahuan dari pengetahuan individual dan bagian dari organisasi. Meskipun penerapan manajemen pengetahuan sudah dalam kategori baik, namun organisasi perlu memperhatikan sub variabel penerapan teknologi karena berdasar data pada sub variabel ini, guru memperlihatkan kekurangpuasan pada media yang diambil oleh madrasah untuk penyebaran praktik yang baik sehingga penerapannya masih kurang optimal. Hal ini sejalan dengan Goodhue yang mengatakan bahwa teknologi (TIK) berperan sebagai media yang mempermudah penyebaran explicit knowledge, jika dimanfaatkan dengan tepat dan memiliki kecocokan dengan tugas yang didukung maka dapat memberikan dampak yang positif terhadap kinerja individu (Goodhue dkk, 1995).

Selanjutnya Honeycutt (2005) berpendapat bahwa dalam praktiknya dapat menjadi pedoman tentang pengelolaan intangible asset yang menjadi pilar organisasi dalam menciptakan nilai.

Kedua, Pengembangan kapasitas guru (PKG) berhubungan dengan fungsi guru sebagai tenaga pendidik. Variabel pengembangan kapasitas guru memiliki empat dimensi yang diteliti sekaitan dengan pengembangan kapasitas guru yaitu dimensi kebijakan PKG, dimensi pengelolaan $\mathrm{PKG}$, dimensi jaminan mutu PKG dan dimensi dampak PKG. Gambaran pengembangan kapasitas guru adalah sebagai berikut: 


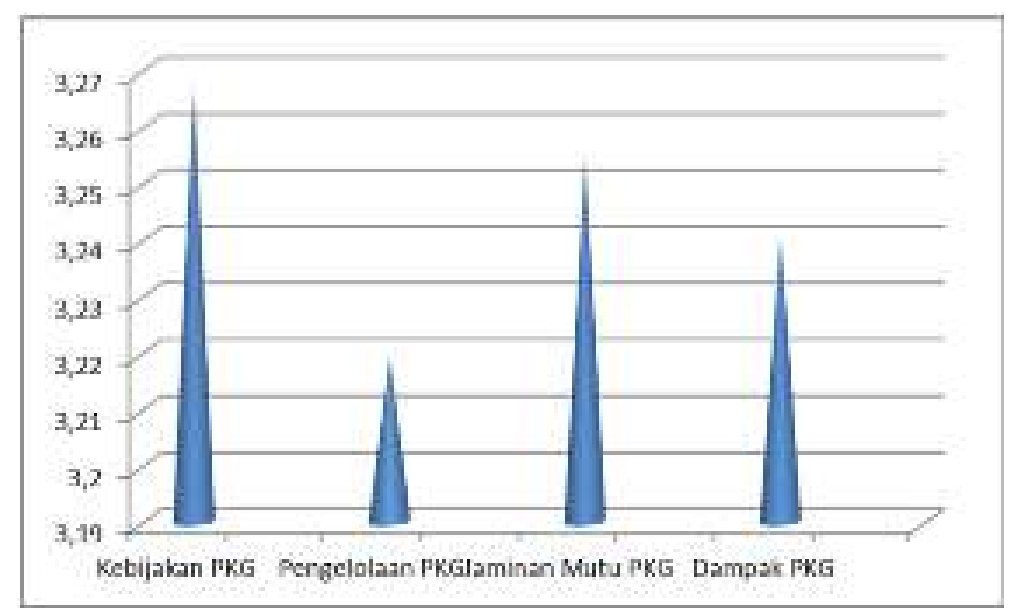

Gambar 3

Deskripsi Pembangunan Kapasitas Guru

Dari gambar 3 diatas, dapat diketahui bahwa variabel pengembangan kapasitas guru memiliki skor rata-rata 3,245 berarti nilai tersebut masuk dalam kategori sedang atau cukup tinggi. Pada dimensi pengembangan kapasitas guru ini nilai tertinggi berada pada dimensi "kebijakan PKG" dengan skor 3,267 dan nilai terendah berada pada dimensi "pengelolaan PKG" dengan skor 3,219. Dimensi ini memiliki indikator proses kebijakan yang menyangkut tentang kepedulian kepala madrasah terhadap kesulitan mengajar yang dialami guru, bagaimana kepala madrasah mampu mengembangkan alternatif solusi dan kemampuan dalam memilih salah satu alternatif terbaik yang dijadikan solusi kebijakan dalam mengatasi permasalahan/kesulitan guru dan kemampuan kepala madrasah dalam membuat ketetapan tentang kebijakan pengembangan kapasitas guru. Dalam kaitan dengan kebijakan pengembangan kapasitas guru, bagaimana madrasah mendokumentasikan kebijakan ini dalam bentuk pencantuman program di Rencana Kerja Madrasah dan memiliki dokumen pedoman pengembangan kapasitas guru di madrasah. Selanjutnya bagaimana kebijakan tersebut didesiminasikan kepada seluruh guru baik dalam bentuk lisan maupun tulisan dalam berbagai forum baik formal maupun informal. Selanjutnya bagaimana kebijakan tersebut ditetapkan oleh pimpinan lembaga terkait menjadi ketetapan bersama seluruh unsur yang terlibat. Seorang pakar kebijakan, (Dunn, 2005) menjelaskan bahwa kebijakan diambil sebagai upaya untuk memecahkan masalah. Kebijakan madrasah terkait pengembangan kapasitas guru didasarkan pada kebutuhan untuk mewujudkan madrasah bermutu. Sejalan dengan pendapat (Noe, 2011) mengenai praktik pengembangan sumber daya manusia, tahapan pertama adalah analisis kebutuhan baik pada tingkat individu maupun organisasi. Penelitian yang sejalan dengan ini dikemukakan oleh (Hill \& Stewart, 2007, hal. 40) bahwa pengembangan sumber daya manusia sebagai intervensi manajemen dengan tujuan untuk meningkatkan kinerja organisasi. Penyelenggaraan pengembangan kapasitas guru merupakan wujud dari pelayanan madrasah terhadap anggotanya yaitu para guru. Keberhasilan memberikan pelayanan kepada guru perlu sistem dan komitmen manajemen. Proses pelayanan tersebut harus mempunyai kriteria seperti yang disampaikan (Mart, 2013) yaitu kemampuan manajerial administrator madrasah, struktur dan proses yang memberikan balikan pekerjaan staf dan pengambilan keputusan di madrasah. Perencanaan pengembangan kapasitas guru di madrasah selama ini disusun berdasarkan kebutuhan untuk 
mewujudkan madrasah yang bermutu meskipun belum melibatkan guru secara keseluruhan. Rangkaian untuk menyusun perencanaan pengembangan kapasitas guru menurut (Gasperz, 2005, hal. 108) bahwa rangkaian pertama yang harus dilakukan dalam perencanaan adalah identifikasi masalah utama, meneliti penyebab utama, menentukan penyebab yang sangat berpengaruh, menyusun rencana perbaikan dan menetapkan sasaran.

Ketiga, berdasarkan hasil temuan penelitian menunjukkan bahwa pengaruh manajemen pengetahuan dan pengembangan kapasitas guru terhadap kinerja mengajar guru, diperoleh korelasi sebagai berikut:

Tabel 1

Koefisien Korelasi Antar Variabel

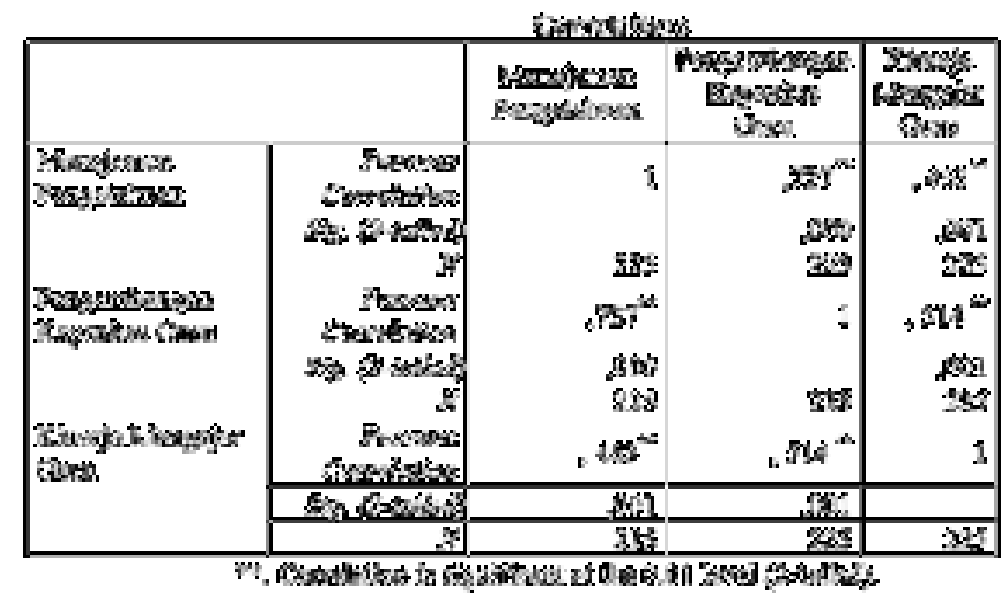

Korelasi antara variabel Manajemen Pengetahuan (X1) dengan variabel Pengembangan Kapasitas Guru (X2) sebesar 0,727 berarti memiliki hubungan yang tinggi nilai signifikansinya adalah 0,000 yang berarti lebih kecil dari 0,05 yang bermakna bahwa ada korelasi yang signifikan, (5) korelasi antara variabel Manajemen Pengetahuan (X1) dengan variabel Kinerja Mengajar Guru (Y) sebesar 0,463 berarti memiliki hubungan yang cukup tinggi, nilai signifikansinya adalah 0,001 yang berarti lebih kecil dari 0,05 yang bermakna bahwa ada korelasi yang signifikan.korelasi antara variabel Pengembangan Kapasitas Guru (X2) dengan variabel Kinerja Mengajar Guru (Y) sebesar 0,514 berarti memiliki hubungan yang cukup tinggi nilai signifikansinya adalah 0,001 yang berarti lebih kecil dari 0,05 yang bermakna bahwa ada korelasi yang signifikan.

Perhitungan analisis jalur pada penelitian ini menggunakan bantuan SPSS. Berikut adalah hasil perhitungan SPSS dalam koefisien jalur:

Tabel 2

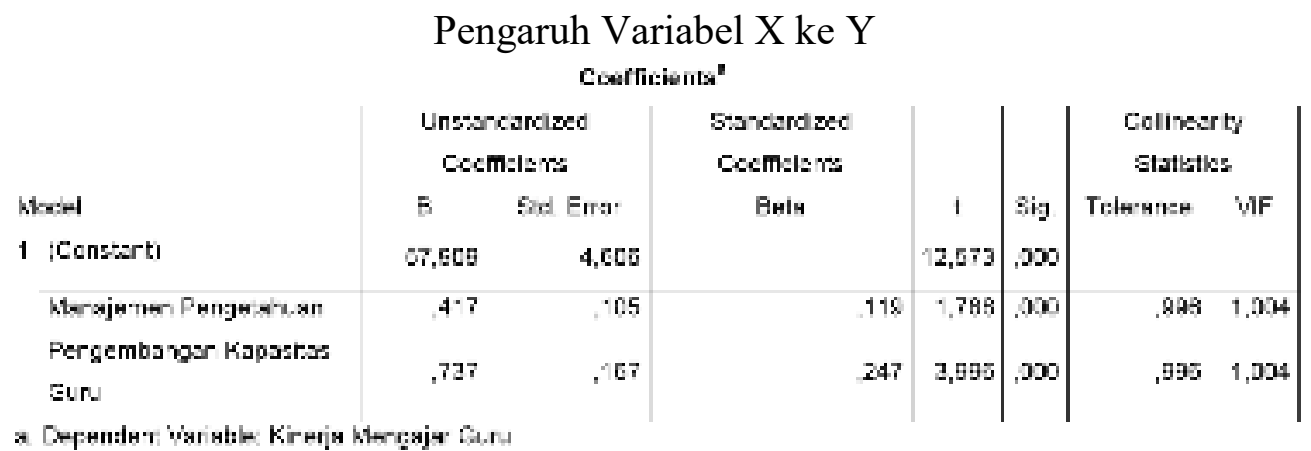


Hasil perhitungan koefisien pengaruh (jalur) pada tabel di atas menunjukkan bahwa variabel manajemen pengetahuan (X1) mempunya koefisien jalur sebesar 0,119 , variabel pengembangan kapasitas guru (X2) mempunyai koefisien jalur sebesar 0,247 . Hal ini menunjukkan bahwa manajemen pengetahuan memiliki pengaruh sebesar 0,119 untuk mempengaruhi kinerja mengajar guru, sedangkan pengembangan kapasitas guru (X2) mempunyai pengaruh yang lebih besar dibanding variabel manajemen pengetahuan sebesar 0,247 dalam mempengaruhi kinerja mengajar guru.

Tabel 3

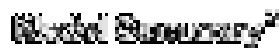

\begin{tabular}{|c|c|c|c|c|c|}
\hline 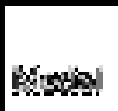 & 暍 & R2spore & 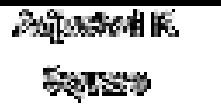 & 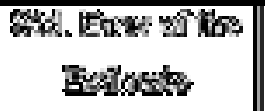 & 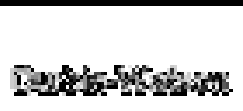 \\
\hline 1 & $\mathrm{WB}^{2}$ & 吗四 & 乘 & 要通的 & $5 \%$ \\
\hline
\end{tabular}

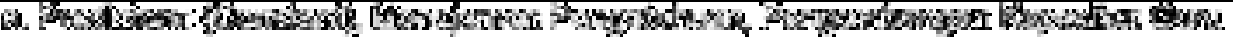

Data di atas menunjukkan bahwa pengaruh secara bersama-sama antara manajemen pengetahuan dan pengembangan kapasitas guru terhadap kinerja mengajar guru sebesar 0,516 (R2=0,516). Hal ini dapat diartikan bahwa pengaruh bersama-sama manajemen pengetahuan dan pengembangan kapasitas guru sebesar 0,516. Selain pengaruh manajemen pengetahuan dan pengembangan kapasitas guru terhadap kinerja mengajar guru, juga terdapat probabilitas munculnya pengaruh variabel lain (residu) yang tidak ada dalam penelitian ini. Adapun besar koefisien jalur pengaruh untuk faktor lain yang tidak ada dalam penelitian ini adalah $\rho y_{-} \varepsilon=\sqrt{ }(10,516)=\sqrt{0,484}=$ 0,6957. Model struktural pengaruh manajemen pengetahuan, pengembangan kapasitas guru terhadap kinerja mengajar guru adalah sebagai berikut:

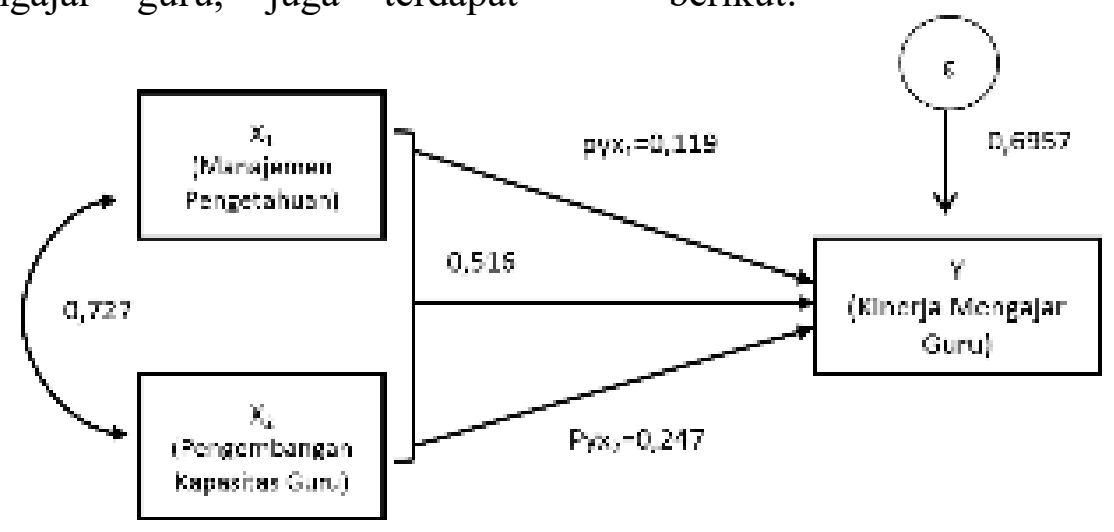

\section{Gambar 4}

Persamaan regresi $\hat{Y}=57,909+0,417$ $\mathrm{X} 1+0,737 \mathrm{X} 2$ dengan nilai koefesien korelasi 0,727 yang berada pada kategori tinggi berdasarkan tabel interpretasi koefesien korelasi. Adapun nilai koefesien determinasi variabel manajemen pengetahuan danpengembangan kapasitas guru terhadap kinerja mengajar guru sebesar
0,516. Angka tersebut menunjukkan bahwa kinerja mengajar guru (Y) dipengaruhi oleh manajemen pengetahuan (X1) dan pengembangan kapasitas guru (X2) secara bersamasama (simultan) sebesar 51,6\%. Hubungan kausial empiris antara X1,X2 terhadap $\mathrm{Y}$ dapat dibuat persamaan 
struktural sebagai berikut: $\rho x 2 \epsilon 1=\rho 21+$ $\rho 21 \epsilon 1=0,516+0,696 \epsilon 1$ sedangkan sisanya sebesar 0,6957 dipengaruhi oleh faktor lain atau epsilon.

Uji Signifikansi variabel pengembangan kapasitas guru dan manajemen pengetahuan terhadap variabel kinerja mengajar guru, berdasarkan pada hasil tabel 2. diatas diketahui bahwa nilai $t$ hitung sebesar 12,573 dengan signifikansi/probabilitas 0,000. Maka sebelum mengambil keputusan harus terlebih dahulu membandingkan antara nilai t hitung dengan $t$ tabel. Apabila $\mathrm{t}$ hitung $\geq \mathrm{t}$ tabel maka dapat dikatakan ada pengaruh yang signifikan dan berlaku sebaliknya, t hitung nya adalah 12,573 dan $t$ tabel nya di cari dengan rumus $(\alpha / 2: n-k 1)$ dengan tingkat kepercayaan $95 \%$ maka nilai $\alpha=0,05$. Jadi $(0,05 / 2: 225-2-1)$ kemudian dicari di t tabel $(0,05: 222)=1,960$ jadi dapat disimpulkan bahwa : $t$ hitung $12,573 \geq$ dari $t$ tabel $1,960=$ signifikan $0,000<0,05=$ signifikanBerdasarkan hasil keputusan tersebut, maka hipotesis dalam penelitian ini adalah adanya pengaruh manajemen pengetahuan dan pengembangan kapasitas guru terhadap kinerja mengajar guru dapat diterima.

Menurut Honeycutt (2005), pengetahuan di bagi menjadi dua jenis yaitu:

1. Tacit Knowledge, pada dasarnya tacit knowledge bersifat personal, dikembangkan melalui pengalaman yang sulit untuk diformulasikan dan dikomunikasikan (Carrillo et al.,2004).

Tacit knowledge dikenal sebagai personal knowledge yaitu gabungan dari pengalaman, nilai - nilai, informasi kontekstual, dan wawasan luas yang menyediakan sebuah kerangka pengetahuan untuk mengevaluasi dan menggabungkan pengalamanpengalaman dan informasi yang baru (Davenport dan Prusak dalam Martin (2010, p. 2).

2. Explicit Knowledge. Secara umum explicit knowledge dapat dijabarkan sebagai:

a. Dapat diucapkan secara tepat dan resmi; dan b. Mudah disusun, didokumentasikan, dipindahkan, dibagi, dan dikomunikasikan.

Yang termasuk dalam explicit knowledge adalah Job Procedure, dikenal sebagai Standard Operation Procedure atau prosedur pelaksanaan dasar dibuat untuk mempertahankan kualitas dan hasil kerja. Dan technology atau teknologi merupakan salah satu elemen pokok yang terdapat pada knowledge management, dikenal sebagai media yang mempermudah penyebaran explicit knowledge. Menurut Marwick (2001) teknologi bukanlah hal baru dalam knowledge management, dan pengalaman yang telah dibentuk oleh para ahli sebelumnya menjadi bahan pertimbangan terbentuknya teknologi itu sendiri. Seiring dengan berjalannya waktu teknologi yang mendukung knowledge management akan selalu berkembang dalam bentuk sistem-sistem yang mempermudah proses penyebaran knowledge. Technology ICT berperan sebagai media yang mempermudah penyebaran explicit knowledge, jika dimanfaatkan dengan tepat dan memiliki kecocokan dengan tugas yang didukung maka dapat memberikan dampak yang positif terhadap kinerja individu (Goodhue dkk, 1995).

Hal-hal yang membuat kedua faktor tersebut berpengaruh terhadap kinerja mengajar guru di MA kota Bandung antara lain, pergaulan dan komunikasi antara sesama rekan kerja terjalin dengan baik, mendengarkan dan memahami keinginan dari para guru, kesempatan yang diberikan kepada guru untuk menunjukkan kapasitasnya sebagai tenaga fungsional yang efektif, bangun sistem yang mengarahkan guru untuk berkolaborasi, melakukan refleksi terhadap setiap praktik kerja, terbuka 
terhadap pemikiran baru dalam pengajaran maupun pembelajaran, fleksibel, menyajikan pembelajaran yang sesuai dengan kebutuhan peserta didik. Dalam mewujudkan kinerjanya guru tetap harus memiliki keyakinan yang melekat pada dirinya dan disadari kebermaknaannya. Sementara itu dalam mewujudkan kinerja guru nampak dari tanggungjawabnya dalam menjalankan amanah, profesi yang diembannya, serta moral yang dimilikinya, yang tercemin dari kepatuhan, komitmen, dan loyalitasnya dalam mengembangkan potensi peserta didik serta memajukan sekolah (Priansa, 2014, hal. 79).

Dalam mengembangkan kapasitas guru dan kemampuan manajemen pengetahuan untuk meningkatkan kinerja mengajar guru perlu dikembangkan suatu komunitas belajar para guru secara profesional yang oleh lunenburg dinyatakan dengan "creating $a$ profesional learning community" yang merupakan bagian dari fungsi madrasah dalam meningkatkan kapasitas guru, sebagaimana telah dilakukan penelitian dan pengembangan sekolah sejak lama oleh para pakar antara lain (Du Four \& Eaker, 1998; Hord, 2003; Huffman \& Hipp, 2003; MartinKniep, 2003; Norris, Barnett, Basom, \& Yakes, 2002; Robert \& Pruitt, 2003; Senge, 1990, 2001; Wald \& Castlebery, 2000; Walsh \& Satetes, 200) dalam (Lunenburg \& Irby, 2006). Dalam kegiatan komunitas belajar para guru di madrasah, dapat dilakukan pertukaran pengetahuan yang menyangkut kapasitas guru dalam mengekplorasi kemampuan mereka berupa tukar pikiran dengan sesama guru, dialog dengan supervisor/pengawas mengenai berbagai hal pengetahuan yang tidak hanya datang dari tingkat atas. Kegiatan ini bisa dilakukan secara menyeluruh/sistemik (Lunenburg \& Irby, 2006). Dengan dikembangkannya komunitas belajar profesional di madrasah, akan menjadikan madrasah sebagai suatu organisasi pembelajar, dimana tempat orang-orang (guru-guru) mengembangkan kapasitasnya secara terus menerus untuk menciptakan hasil-hasil yang mereka inginkan, sesuai dengan pola pikir baru dan aspirasi kolektif yang bebas untuk tumbuh dan berkembang. Oleh karena itu, organisasi pembelajar akan memungkinkan organisasi dan individu yang ada didalamnya tidak terjebak kepada pengulangan hal-hal yang sudah menjadi kebiasaan, kemampuan dan kemauan untuk belajar dan bekerjasama dalam satu tim, didalamnya terdapat semangat dan kemampuan seluruh anggota untuk saling mengajarkan dan berbagi pengetahuan dan bekerjasama sebaai satu kesatuan. Dalam mengembangkan kapasitas yang berkaitan dengan manajemen pengetahuan ini, perlu dikembangkan budaya kerja kreatif di tingkat madrasah yang berorentasi prestasi, sehingga setiap guru diharapkan mampu mengembangkan kesediaan untuk menerima perubahan, mendorong gagasan baru, mengijinkan lebih banyak interaksi, mentoleransi kegagalan, menentukan sasaran yang jelas dan memberikan kebebasan untuk mencapainya dan memberi penghargaan.

\section{E. SIMPULAN DAN SARAN}

Pengaruh manajemen pengetahuan terhadap kinerja mengajar guru teridentifikasi sedang atau cukup, urutan kekuatan korelasinya ada pada aspek personal, prosedur dan teknologi. Pengaruh pengembangan kapasitas guru (PKG) terhadap kinerja mengajar guru dengan kategori sedang atau cukup, urutan kekuatan korelasinya ada pada aspek kebijakan, jaminan mutu, dampak dan pengelolaan PKG. Pengaruh pengembangan kapasitas guru dan manajemen pengetahuan terhadap kinerja mengajar guru teridentifikasi cukup tinggi.

Saran pertama, bagi kepala madrasah sebagai pimpinan organisasi, tingkatkan dan kembangkan kesadaran diri pada pemahaman dan penerimaan terhadap diri melalui kegiatan diklat dan atau melalui kegiatan berbagi pengetahuan 
(knowledge sharing) yang memberikan kemampuan untuk dapat mengenali dan menggali kekuatan dan kelemahan diri.

Saran kedua, tingkatkan daya kreativitas dan inovatif guru dalam kinerja mengajar di lingkungan madrasah dalam mengembangkan budaya akademik dengan membentuk komunitas belajar profesional (proffessional learning community) secara formal dan terkendalikan sebagai upaya efesiensi dalam pengembangan kapasitas guru.

Ketiga, program tersturktur pengembangan kapasitas guru yang mengarah kepada peningkatan kinerja mengajar guru mesti didasarkan pada analisis kebutuhan setiap individu guru dan mata pelajaran yang diampunya.

Dan terakhir, penyediaan infrastruktur berupa teknologi yang sesuai dengan kondisi terkini (up to date) untuk mendukung keterlaksanaan program manajemen pengetahuan dalam kerangka pengembangan kapasitas guru, guna menuju kinerja terbaik secara personal maupun kelompok.

\section{DAFTAR PUSTAKA}

Bernardin, H., \& Russell, J. (1993). Human Resources Management. Singapore: Mc. Graw Hill, Inc.

Bhatt, G. (2000). Organizing Knowledge in The Knowledge Development Cycle. Journal of Knowledge Management, 4(1), 15-26.

Casio, W. (1992). Managing Human Resources: Productivity, Quality of Work Life, Profit. Singapore: McGraw Hill Inc.

Corrilo, P., Robinson, G., \& Inba, A. (2004). Knowledge Mnagement in UK Construction Strategies, Resources and Barriers. Project Management Journal, 1, 46-60.

Dunn, W. (2000). Public Policy Analysis: An Introduction. New Jersey: PrenticeHall,Inc.A Simon \& Shuster Company.
Frappaolo, C. (2006). Knowledge Management. England: Cap Stone Publishing.

Gaspez, V. (2005). Total Quality Managment. Jakarta: Gramedia.

Gomes, F. (2003). Manajemen Sumber Daya Manusia. Yogyakarta: Andi Offset.

Goodhue, D., \& Thomshon, R. (1995). TaskTechnology and Fit Individual Performance. MIS Quarterly, 19(2), 213-236.

Griffin, R. (1987). Management. Boston: Hougthon Miffin.

Hill, R., \& Stewart, J. (2007). Management Development. Lancester: Routledge.

Honeycutt, J. (2005). Knowledge Management Strategies. New Jersey: Prentice-Hall.

L.Gibson, J., Ivancevich, J. M., \& Donnelly, J. H. (1994). Organization. Houston: Businerss Publication, Inc.

Lunenburg, F., \& Irby, B. (2006). The Principalship: Vision to Action. Houston: Wadsworth Cengage Learning.

Marsick, V., \& Watkins, W. (2001). The Learning Organization: an Integrative Vision for HRD. Human Resources Development Quarterly, 3(1), 353-361.

Mart, C. (2013). Commitment to School and Student. International Journal of Academic Research in Business and Social Science, 3(1), 336-340.

Martini, H. (2010). Pengaruh Kompetensi Karyawan dan Budaya Organisasi terhadap Kinerja Karyawan . Widyagama, 53-63.

Noe, R. (2011). Manajemen Sumber Daya Manusia. Jakarta: Salemba.

Priansa, D. J. (2014). Kinerja dan Profesionalisme Guru. Bandung: Alfabeta. 
PEDAGOGIA : Jurnal Ilmu Pendidikan

Rivai, V. (2005). Performance Appraisal. Jakarta: Raja Grafindo Persada.

Simamora, H. (2004). Manajemen Sumber Daya Manusia. Yogyakarta: YYKPN.

Skyrme, D. (2002). What's Next for Knowledge Management? up date Entovation International News 